Original Research Paper

\title{
Komparasi Kelimpahan Serangga di Kawasan Rawa yang Dikonversi di Jalan Soekarno Hatta Palembang
}

\author{
Novin Teristiandi ${ }^{*}$ \\ ${ }^{1}$ Program Studi biologi, UIN Raden Fatah Palembang, Indonesia
}

\author{
Riwayat artikel \\ Received : 16 Desember 2019 \\ Revised : 31 Desember 2019 \\ Accepted : 14 Januari 2020 \\ Published : 28 Januari 2020 \\ *Corresponding Author: \\ Novin Teristiandi, \\ UIN Raden Fatah Palembang, \\ Indonesia. \\ Email: \\ novinteristiandi uin@ radenfatah.ac.id
}

\begin{abstract}
Abstrak: Kegiatan alih fungsi lahan basah banyak terjadi di kecamatan Ilir barat I sekitar jalan soekarno hatta Palembang. Aktivitas alih fungsi lahan ini dapat menghilangkan dan merusak habitat bagi biodiversitas khususnya serangga di area tersebut. Penelitian ini bertujuan untuk mempelajari keanekaragaman dan kelimpahan serangga yang ada di kawasan jalan Soekarno Hatta Palembang. Penelitian ini menggunakan metode survei, yaitu penyelidikan yang dilakukan untuk memperoleh sata dari kondisi yang ada dan mencari keterangan secara faktual dari suatu daerah. Hasil penelitian ini ditemukan 109 spesies, 56 famili dan 10 ordo. Berdasarkan jumlah spesies dari masing-masing lokasi/stasiun survei menunjukan bahwa di ST 1 (rawa alami) ditemukan 77 spesies, ST 2 (rawa yang telah ditimbun) ditemukan 53 spesies, ST 3 (rawa yang telah dijadikan pemukiman) ditemukan 50 spesies, dan ST 4 (rawa yang telah dibangun perukoan) ditemukan 57 spesies serangga. Rawa alami memiliki keanekaragaman dan kelimpahan serangga tertinggi, sedangkan lahan rawa yang telah di konversi menjadi pemukiman memiliki keanekaragaman dan kelimpahan terendah. Hasil penelitian membuktikan bahwa alih fungsi lahan rawa mempengaruhi keanekaragaman dan kelimpahan serangga di kawasan jalan Soekarno Hatta Palembang.
\end{abstract}

Kata kunci: keanekaragaman, kelimpahan, serangga, sumatera, rawa

Abstract: Wetland conversion activities occur mostly in Ilir Barat I subdistrict around the Soekarno Hatta Road in Palembang. This land conversion activity can eliminate and destroy habitat for biodiversity, especially insects in the area. This research was conducted to study the diversity and abundance of insects in the Soekarno Hatta Palembang road area. The research method used in this study is a survey method, which is an investigation carried out to obtain data from the area. The results of this study found 109 species, 56 families and 10 orders. Based on the number of species from each survey location / station, it was found that in ST 1 (natural swamp) was found 77 species, ST 2 (stockpiled swamp) was found 53 species, ST 3 (swamp which had been made a settlement) was found 50 species, and ST 4 (swamps that have been built by shop houses) was found 57 species. ST1 have the highest diversity and abundance of insects, while ST3 have the lowest diversity and abundance. The results of the study prove that the conversion of swamp land has an effect on diversity and abundance of insects in Soekarno Hatta road, Palembang.

Keywords: diversity, abundance, insects, Sumatera, swamps 


\section{Pendahuluan}

Serangga merupakan organisme yang mudah dijumpai di permukaan bumi, hal tersebut dikarenakan serangga mempunyai jumlah yang sangat banyak dan daerah persebaran yang luas. Serangga merupakan golongan binatang yang terbesar, kira-kira $75 \%$ dari jumlah binatang yang telah diketahui manusia adalah serangga (Pracaya, 2003). Salah satu keanekaragaman hayati yang dapat dibanggakan Indonesia adalah serangga, dengan jumlah 250.000 jenis atau sekitar $15 \%$ dari jumlah jenis biota utama yang diketahui di Indonesia (BAPPENAS, 1993). Hal ini menunjukan bahwa serangga merupakan salah satu komponen utama dalam ekosistem, termasuk di ekosistem rawa.

Rawa lebak adalah istilah rawa non pasang surut di daerah Sumatera Selatan. Ditinjau dari aspek potensi, secara umum lahan lebak sebenarnya lebih baik dari lahan pasang surut, oleh karena itu akan memudahkan berbagai jenis hewan untuk tumbuh berkembang (Subagya, 2006). Kota Palembang berdasarkan hasil perhitungan peta, luas Kota Palembang seluas $36.484 \mathrm{Ha}, 54 \%$ diantaranya merupakan lahan rawa yang digunakan sebagai daerah resapan air Kota Palembang. Seiring dengan semakin berkembangnya Kota Palembang dan dengan adanya kebutuhan pembangunan maka lahan rawa ini tersentuh untuk dijadikan areal terbangun (Febriana, 2008). Berdasarkan hasil pantauan secara langsung di lapangan, pada tahun 2012 masih terdapat beberapa aktivitas penimbunan rawa yang terjadi di beberapa kawasan di kota Palembang, seperti kawasan Jakabaring, jalan Soekarno Hatta, jalan Lunjuk Jaya, Kalidoni, dan Demang Lebar Daun (Shofix, 2012).

Alih fungsi lahan rawa dapat mempengaruhi keberadaan serangga di ekosistem rawa. Keanekaragaman serangga adalah bagian penting dari keanekaragaman lahan basah, yang terkait erat dengan vegetasi di ekosistem lahan basah. Banyak faktor lingkungan mempengaruhi keanekaragaman serangga lahan basah, dan suksesi vegetasi adalah faktor kunci. Karena sensitivitas terhadap perubahan lingkungan lahan basah, keanekaragaman serangga secara bertahap diterapkan sebagai indikator untuk pemantauan dan evaluasi kualitas lahan basah, dan penting untuk studi konservasi dan restorasi lahan basah (Lan et al., 2012).

Berdasarkan hasil survei di kecamatan ilir barat I kawasan jalan Soekarno Hatta Palembang, ditemukan rawa alami, rawa yang telah ditimbun, rawa yang telah dijadikan pemukiman warga, dan rawa yang telah dibangun perukoan, selain itu juga ditemukan beberapa jenis serangga di masing-masing daerah tersebut. Aktivitas penimbunan dan pemukiman ini, tentu akan mempengaruhi komponen ekosistem yang ada termasuk serangga. Oleh karena itu, perlu dilakukan penelitian mengenai keanekaragaman dan kelimpahan di rawa alami, rawa yang telah dialihfungsikan. Penelitian ini bertujuan untuk mempelajari keanekaragaman dan kelimpahan serangga di rawa yang telah dikonversi/ dialih fungsikan di kawasan jalan Soekarno Hatta Palembang, mengingat jumlah rawa di kota Palembang sudah jauh berkurang.

\section{Bahan dan Metode}

\section{Lokasi Penelitian}

Semua tahapan Penelitian ini dilaksanakan selama 7 bulan. Penelitian ini dilakukan di kawasan Rawa yang ada di Jalan Soekarno Hatta Palembang. Pengambilan sampel dilakukan sebanyak 3 kali survei setiap stasiun. Wilayah penelitian dibagi menjadi beberapa stasiun yang ditentukan dengan metode Survei. Wilayah ini memiliki 4 stasiun yang terdiri dari zona rawa alami (ST1), zona rawa yang telah di timbun (ST2), zona rawa yang telah menjadi pemukiman warga (ST3), dan zona rawa yang telah dibangun perukoan (ST4).

\section{Teknik Pengumpulan Data}

Survei dan eksplorasi tersebut dilakukan dengan menggunakan transek garis sejauh $1 \mathrm{~km}$ pada setiap stasiun, tapi jika panjang satu lokasi atau stasiun yang memungkinkan tidak mencapai jarak tersebut, maka diadakan pembelokan ke arah semula dengan jarak $1 \mathrm{~m}$ dari garis yang telah dilewati (Khan, 2007). Pengumpulan data dengan cara pencuplikan langsung (hand picking) dan perangkap serangga. Jenis perangkap serangga yang digunakan untuk menangkap serangga permukaan tanah adalah: pitfall trap, light trap dan sticky trap.

\section{Analisis Data}

Analisis data dilakukan berdasarkan keanekaragaman spesies (jumlah spesies yang ditemukan) dan kelimpahan spesies serangga di setiap stasiun penelitian. Komunitas serangga di lahan yang dikonversi dibandingkan dengan stasiun kontrol menggunakan Shannon diversity index (H') and Simpson domination index (D) (Odum, 1983), untuk mendapatkan perbandingan komposisi komunitas semut di setiap titik sampling.

\section{Hasil dan Pembahasan}

Keanekaragaman serangga di Rawa Kawasan Jalan Soekarno Hatta Palembang 
Penelitian ini dilakukan di empat stasiun penelitian yaitu rawa alami, rawa yang telah ditimbun, rawa yang telah dijadikan pemukiman, dan rawa yang telah dijadikan perukoan. Hasil penelitian pada Tabel 4.3 ini menunjukan bahwa di ST1 (rawa alami) ditemukan 77 spesies, ST2 (rawa yang telah ditimbun) ditemukan 53 spesies, ST3 (rawa yang telah dijadikan pemukiman) ditemukan 50 spesies, dan ST4 (rawa yang telah dijadikan perukoan) ditemukan 57 spesies serangga. Untuk lebih lengkapnya terdapat pada tabel 1.

Tabel 1. Keanekaragaman spesies serangga di setiap stasiun pengambilan sampel di rawa kawasan jalan Soekarno Hatta Palembang Sumatera Selatan

\begin{tabular}{|l|l|l|l|l|l|l|}
\hline \multirow{2}{*}{ No } & \multirow{2}{*}{ Ordo } & \multicolumn{4}{|c|}{ Keanekaragaman } & \multirow{2}{*}{$\sum$} \\
\cline { 3 - 6 } & & ST1 & ST2 & ST3 & ST4 & \\
\hline 1 & Blatodea & 1 & 1 & 2 & 1 & 3 \\
\hline 2 & Coleoptera & 12 & 7 & 9 & 10 & 20 \\
\hline 3 & Diptera & 10 & 10 & 10 & 9 & 14 \\
\hline 4 & Hemiptera & 11 & 5 & 5 & 6 & 14 \\
\hline 5 & Hymenoptera & 20 & 11 & 11 & 14 & 25 \\
\hline 6 & Lepidoptera & 4 & 3 & 2 & 3 & 7 \\
\hline 7 & Mantodea & 0 & 0 & 1 & 0 & 1 \\
\hline 8 & Neuroptera & 1 & 0 & 0 & 0 & 1 \\
\hline 9 & Odonata & 8 & 6 & 4 & 6 & 8 \\
\hline 10 & Orthoptera & 10 & 10 & 6 & 8 & 15 \\
\hline & Total & 77 & 53 & 50 & 57 & 108 \\
\hline
\end{tabular}

Catatan : ST1 (rawa alami), ST2 (rawa yang telah ditimbun), ST3 (rawa yang telah menjadi pemukiman), ST4 (rawa yang telah dibangun perukoan).

Jumlah spesies tertinggi ditemukan di ST1 (rawa alami), yaitu 77 Spesies dan jumlah spesies yang paling rendah ditemukan di ST3 (rawa yang sudah dijadikan pemukiman) yaitu 50 spesies. Untuk lebih jelas dapat dilihat pada gambar diagram di bawah ini.

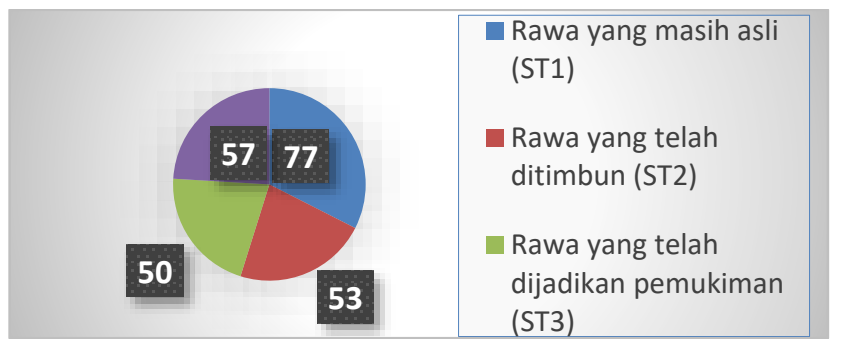

Gambar 1. Diagram jumlah spesies di lokasi penelitian

Hasil Penelitian menunjukan bahwa ditemukan 108 spesies, 56 famili dan 10 ordo. 10 ordo serangga yang ditemukan yaitu Blatodea, Coleoptera, Diptera, Hemiptera, Hymenoptera, Lepidoptera, Mantodea, Neuroptera, Odonata, dan Orthoptera.

Hasil penelitian menunjukan terdapat ordo, famili dan spesies yang ditemukan pada 1 stasiun penelitian saja dan terdapat juga spesies yang ditemukan di seluruh stasiun penelitian. Berdasarkan jumlah spesies dari masing-masing ordo, Blatodea ditemukan 3 spesies, ordo Coleoptera ditemukan 20 spesies, ordo Diptera ditemukan 14 spesies, ordo Hemiptera ditemukan 14 spesies, ordo Hymenoptera ditemukan 25 spesies, ordo Lepidoptera ditemukan 7 spesies, ordo Mantodea ditemukan 1 spesies, ordo Neuroptera ditemukan 1 spesies, ordo Odonata ditemukan 8 spesies dan ordo Orthoptera ditemukan 15 spesies (Gambar 2).

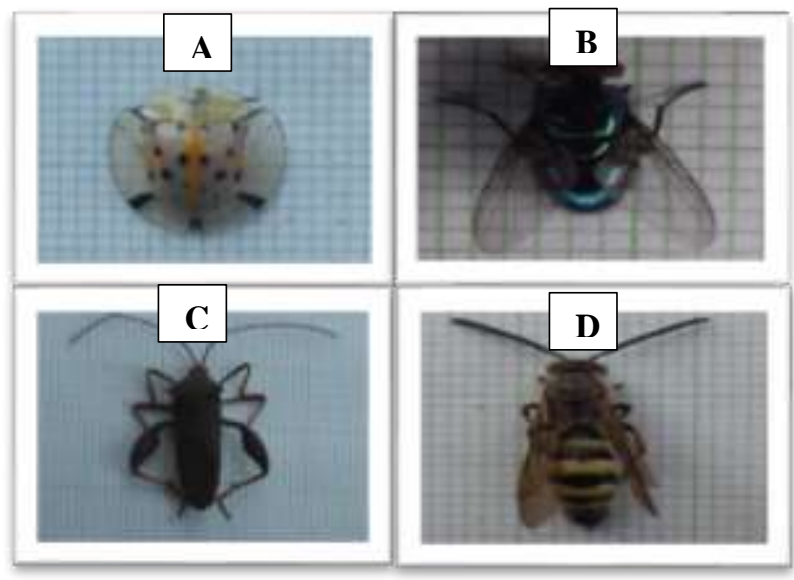

Gambar 2. Ordo Serangga yang memiliki keanekaragaman yang tinggi

(A: Coleoptera; B: Diptera; C: Hemiptera; D: Hymenoptera)

Jumlah spesies di rawa yang telah dijadikan pemukiman adalah yang terendah yaitu 50 spesies, sedangkan pada rawa alami menunjukan jumlah atau keanekaragaman spesies tertinggi yaitu 77 spesies. Perbedaan ini diduga karena selain dipengaruhi oleh aktivitas manusia dalam membuka lahan, dan struktur vegetasi sebagai habitat serangga. Pernyataan ini didukung oleh studi Putri dan Allo (2007) bahwa keanekaragaman hayati kawasan konservasi dipengaruhi oleh aktivitas manusia atau penduduk. Purba (2002) mengemukakan bahwa kegiatan di daerah pemukiman dan pertanian mengakibatkan terjadinya perubahan sifat fisik dan kimia perairan serta berpengaruh terhadap komposisi dan jumlah jenis organisme. Konsekuensinya dari keadaan tersebut adalah terjadinya degradasi keanekaragaman hayati pada kawasan yang berdekatan dengan pemukiman. 
Kelimpahan Seranga di Rawa Kawasan Jalan Soekarno Hatta Palembang

Kelimpahan spesies serangga di rawa kawasan jalan Soekarno Hatta Palembang bervariasi. Ditinjau dari lokasi/stasiun penelitian, kelimpahan serangga tertinggi ditemukan di rawa alami (ST1) yaitu 1002 individu, kelimpahan terendah ditemukan di rawa yang telah dijadikan pemukiman (ST3) yaitu 498 individu. Ditinjau dari spesies, kelimpahan spesies serangga tertinggi yaitu Culex quinquefasciatus dari ordo Diptera dan kelimpahan spesies terendah adalah 1 individu, ditemukan pada beberapa spesies. Ditinjau dari famili, kelimpahan spesies serangga tertinggi ditemukan pada famili formicidae ordo Hymenoptera yaitu 1136 individu, sedangkan kelimpahan serangga terendah ditemukan 1 individu pada beberapa famili. Ditinjau dari ordo, kelimpahan spesies tertinggi ditemukan pada ordo Hymenoptera yaitu 1354 individu, sedangkan kelimpahan spesies serangga terendah ditemukan pada ordo Mantodea dan Neuroptera yaitu 1 individu.

Tabel 2. Kelimpahan serangga terestrial dan akuatik setiap stasiun pengambilan sampel di rawa jalan Soekarno Hatta Palembang Sumatera Selatan

\begin{tabular}{|l|l|l|l|l|l|l|}
\hline \multirow{2}{*}{ No } & \multirow{2}{*}{ Ordo } & \multicolumn{4}{|c|}{$\begin{array}{c}\text { Jumlah Serangga } \\
\text { (individu) }\end{array}$} & \multirow{2}{*}{$\sum$} \\
\cline { 3 - 7 } & & ST1 & ST2 & ST3 & ST4 & \\
\hline 1 & Blatodea & 1 & 6 & 4 & 1 & 12 \\
\hline 2 & Coleoptera & 37 & 12 & 29 & 20 & 98 \\
\hline 3 & Diptera & 413 & 393 & 159 & 65 & 1030 \\
\hline 4 & Hemiptera & 48 & 51 & 24 & 28 & 151 \\
\hline 5 & Hymenoptera & 405 & 198 & 222 & 529 & 1354 \\
\hline 6 & Lepidoptera & 13 & 15 & 19 & 5 & 52 \\
\hline 7 & Mantodea & 0 & 0 & 1 & 0 & 1 \\
\hline 8 & Neuroptera & 1 & 0 & 0 & 0 & 1 \\
\hline 9 & Odonata & 19 & 22 & 14 & 22 & 77 \\
\hline 10 & Orthoptera & 65 & 89 & 26 & 53 & 233 \\
\hline & Total & 1002 & 786 & 498 & 723 & 3009 \\
\hline
\end{tabular}

Catatan: ST1 (rawa alami), ST2 (rawa yang telah ditimbun), ST3 (rawa yang telah menjadi pemukiman),dan ST4 (rawa yang telah dibangun perukoan), * Jumlah tertinggi.

Kelimpahan spesies tertinggi ditemukan di rawa alami yaitu 1002 individu, sedangkan kelimpahan serangga terendah ditemukan di stasiun rawa alami yaitu 498 individu. Untuk lebih jelasnya dapat di lihat pada gambar 2 di bawah ini.

Hasil penelitian menunjukan bahwa keanekaragaman dan kelimpahan ordo tertinggi ditemukan pada Ordo Hymenoptera di rawa alami dan pemukiman, sedangkan yang terendah ditemukan pada ordo Mantodea dan Neuroptera di pemukiman dan rawa alami.

Hasil penelitian menunjukan jumlah serangga ordo Hymenoptera tertinggi khususnya famili formicidae ditemukan di rawa yang telah dijadikan perukoan dan pemukiman. Hal ini dikarenakan, serangga ini biasa hidup di tanah dan pemukiman, seperti yang dikemukakan oleh Taib (2013) bahwa semut biasa hidup di tanah (baik dataran rendah maupun dataran tinggi/gunung) yang memiliki suhu sedang. Hasil survei menunjukan bahwa zona rawa yang yang telah dibangun perukoan dan pemukiman terdapat banyak wilayah terestrial dan suhunya $30^{\circ} \mathrm{C}$, sehingga serangga dapat ditemukan di rawa yang telah dibangun perukoan dan pemukiman, dibandingkan rawa asli yang lebih sedikit wilayah terestrial. Selain itu mereka juga hidup berkoloni sehingga lebih mudah ditemukan.

Habitat Mantodea biasanya hidup di antara tanaman-tanaman dan rumput. Mantodea biasanya melakukan penyamaran untuk melindungi diri dengan tinggal diantara tanaman, hal ini juga berguna untuk menangkap mangsanya. Selain itu mereka juga dapat beradaptasi dengan menirukan atau menyerupakan diri seperti daun, batang, ujung daun, rumput, bunga, atau kadang-kadang batu (Mathias, 2015). Kesulitan dalam mengenali dan menangkap serangga ordo ini menyebabkan hanya satu serangga Mantodea saja yang berhasil ditangkap dalam penelitian ini. Selain itu serangga ordo ini merupakan serangga predator yang kelimpahannya sedikit.

Serangga ordo Neuroptera sangat sulit ditemukan, karena menurut PPLH (2007) Ordo Neuroptera menyembunyikan dirinya pada tanah gembur. Pada malam hari ia akan meninggalkan sarangnya untuk berburu mangsa. Selain itu, pengaruh pencemaran tanah akibat aktivitas manusia juga mempengaruhi kelimpahan ordo ini.

Kelimpahan serangga pada tiap-tiap lokasi survei berhubungan dengan keberadaan habitat, vegetasi, aktivitas manusia dan ketersediaan makanan bagi serangga. Pada rawa alami, lingkungannya masih terdapat banyak vegetasi dan sedikit aktivitas manusia, sehingga rawa alami mempunyai ketersediaan makanan lebih banyak. Pada penelitian ini lokasi survei atau stasiun penelitian yang lebih tinggi mendapat gangguan ditemukan kelimpahan atau jumlah serangga yang paling rendah, sedangkan lokasi survei atau stasiun penelitian yang sedikit mendapat gangguan, ditemukan serangga yang lebih banyak atau kelimpahannya lebih tinggi. Hasil ini selaras dengan penelitian Rasdi et al. (2012) yang menyatakan adanya perbedaan kelimpahan serangga akuatik di sungai Keinam, Malaysia karena 
serangga akuatik bervariasi dan tidak konstan pada suatu habitat relatif lokasinya menyediakan suplai makanan yang banyak dan tidak ada gangguan dari musuh alami. Kenyataan di lapangan, kelimpahan serangga pada lokasi yang memiliki vegetasi yang lebih rimbun dan kurang aktivitas manusia mempunyai kelimpahan yang lebih tinggi, yaitu rawa alami (1002 individu/m2) dibandingkan dengan rawa yang telah di jadikan pemukiman yang memiliki kelimpahan serangga yang lebih rendah (498 individu/m2).

\section{Indeks Keanekaragaman, Dominansi, dan Kemerataan} Serangga di Rawa Jalan Soekarno Hatta Palembang

Hasil analisis data, kelimpahan, indeks keanekaragaman spesies, indeks dominansi dan indek kemerataan dapat dilihat pada tabel 3, untuk lebih jelas, indeks keanekaragaman spesies serangga terrestrial dan akuatik Rawa Jalan Soekarno Hatta Palembang dapat dilihat pada tabel 3 dan 4 di bawah ini.

Tabel 3. Keanekaragaman spesies serangga berdasarkan lokasi penelitian

\begin{tabular}{|l|l|l|l|l|}
\hline \multirow{2}{*}{$\begin{array}{c}\text { Karakteristik } \\
\text { Komunitas }\end{array}$} & \multicolumn{4}{c|}{ Lokasi } \\
\cline { 2 - 5 } ST1 & ST2 & ST3 & ST4 \\
\hline Kelimpahan/jumlah & 1002 & 786 & 498 & 723 \\
\hline Jumlah Spesies & 77 & 53 & 50 & 57 \\
\hline
\end{tabular}

\begin{tabular}{|l|l|l|l|l|}
\hline $\begin{array}{l}\text { Indeks } \\
\text { Keanekaragaman }\end{array}$ & 2,70 & 2,42 & 2,97 & 2,23 \\
\hline Indeks Dominansi & 0,16 & 0,22 & 0,10 & 0,27 \\
\hline Indeks Kemerataan & 0,62 & 0,61 & 0,76 & 0,55 \\
\hline
\end{tabular}

Tabel 3 dan Tabel 4 memperlihatkan keanekaragaman dan kelimpahan serangga yang bervariasi ditinjau dari lokasi/stasiun survei dan ordo serangga. Kelimpahan dan keanekaragaman spesies tertinggi berada di rawa alami, indeks keanekaragaman dan indek skemerataan spesies tertinggi berada di rawa yang telah menjadi pemukiman sedangkan indeks dominansi tertinggi berada di rawa yang telah menjadi kawasan perukoan. Jumlah spesimen, jumlah spesies dan indeks dominansi spesies terendah ditemukan di rawa yang telah menjadi pemukiman sedangkan indeks keanekaragaman dan kemerataan spesies terendah ditemukan di rawa yang telah menjadi kawasan perukoan. Ditinjau dari lokasi survei secara keseluruhan indeks keanekaragaman menunjukan $1<\mathrm{H}<3$ yang artinya tingkat keragaman serangga adalah sedang, sedangkan indeks dominansi menunjukan $\mathrm{C}<0,50$ yang artinya dominasi rendah, dan indeks kemerataan menunjukan 0,76 - 0,95 yang artinya hampir merata.

Tabel 4.8. Keanekaragaman spesies serangga terestrial dan akuatik berdasarkan ordo serangga di rawa jalan Soekarno Hatta Palembang

\begin{tabular}{|c|c|c|c|c|c|c|c|c|c|c|}
\hline \multirow{2}{*}{$\begin{array}{l}\text { Karakteristik } \\
\text { Komunitas }\end{array}$} & \multicolumn{10}{|c|}{ Ordo Serangga } \\
\hline & Bl & Co & Di & $\mathrm{He}$ & Hy & Le & Ma & $\mathrm{Ne}$ & Od & Or \\
\hline $\begin{array}{l}\text { Kelimpahan/jumlah } \\
\text { Spesimen }\end{array}$ & 12 & 98 & 1030 & 151 & 1354 & 52 & 1 & 1 & 77 & 233 \\
\hline Jumlah Spesies & 3 & 20 & 14 & 14 & 25 & 7 & 1 & 1 & 9 & 15 \\
\hline $\begin{array}{l}\text { Indeks Keanekaragaman } \\
\text { Spesies }\end{array}$ & 0,024 & 0,19 & 0,63 & 0,24 & 1,22 & 0,09 & 0,0027 & 0,0027 & 0,14 & 0,35 \\
\hline $\begin{array}{l}\text { Indeks Dominansi } \\
\text { Spesies }\end{array}$ & 0 & 0,0001 & 0,082 & 0,0006 & 0,045 & 0,0001 & 0 & 0 & 0,0001 & 0,0013 \\
\hline $\begin{array}{l}\text { Indeks Kemerataan } \\
\text { Spesies }\end{array}$ & 0,005 & 0,041 & 0,13 & 0,051 & 0,26 & 0,02 & 0,0006 & 0,0006 & 0,03 & 0,075 \\
\hline
\end{tabular}

Catatan : Bl (Blatodea), Co (Coleoptera), Di (Diptera), He (Hemiptera), Hy (Hymenoptera), Le (Lepidoptera), Ma (Mantodea), Ne (Neuroptera), Od (Odonata), dan Or (Orthoptera).

Keanekaragaman dan kelimpahan serangga bila ditinjau dari ordo maka kelimpahan, jumlah spesies dan indeks kemerataan spesies tertinggi ditemukan pada ordo Hymenoptera, sedangkan kelimpahan, jumlah spesies dan indeks kemerataan spesies terendah ditemukan pada ordo Mantodea dan Neuroptera. Indeks keanekaragaman dan indeks dominansi spesies tertinggi ditemukan pada ordo Diptera sedangkan Indeks keanekaragaman dan indeks dominansi spesies terendah ditemukan pada ordo Mantodea dan Neuroptera. Ditinjau dari ordo secara keseluruhan Indeks keanekaragaman menunjukan $\mathrm{H}<1$ artinya tingkat keragaman serangga adalah rendah, sedangkan indeks dominansi menunjukan $\mathrm{C}<0,50$ yang artinya dominasi rendah, dan Indeks kemerataan menunjukan $0,00-0,25$ artinya tidak merata.

Hasil analisis data, kelimpahan dan keanekaragaman spesies dipengaruhi oleh 
kompleksitasnya habitat atau faktor biotik dan abiotik, seperti yang dikatakan oleh Syahrawati dan Hamid (2010) ada beberapa faktor yang mempengaruhi diversitas serangga antara lain tipe habitat, arsitektur tanaman, dan senyawa kimia tumbuhan. Selain itu, menurut Syahrawati dan Hamid (2010), diversitas serangga juga dipengaruhi oleh perubahan dan gangguan habitat, namun pengaruhnya berbeda pada setiap jenis serangga. Famili Formicidae mampu merespon perubahan lingkungan dengan baik, dan terbukti pada penelitian di jalan Soekarno Hatta Palembang, kelimpahan serangga dan keanekaragaman spesies tetinggi ada pada ordo Hymenoptera. Beberapa organisme lebih sensitif terhadap perubahan lingkangan, namun terdapat organisme yang lebih toleran terhadap perubahan lingkunngan (Teristiandi, 2018). Perbedaan kemampuan survive dalam merespon perubahan factor lingkungan inilah yang menjadi salah satu penyebab terdapat spesies yang mendominasi ekosistem.

Akibat alih fungsi rawa ini, maka secara ekologis berpengaruh terhadap struktur, komposisi dan fungsi dari rawa jalan Soekarno Hatta Palembang. Tutupan vegetasi semakin berkurang, fauna kehilangan habitat, kematian flora dan fauna, terjadi perubahan cuaca, dan mata air. Lebih jauh kerusakan rawa akan mengakibatkan kerusakan biotik dan abiotik yang sangat mempengaruhi fungsi kawasan serta kehidupan serangga. Hasil penelitian membuktikan bahwa alih fungsi lahan atau pembukaan lahan rawa mempengaruhi keanekaragaman dan kelimpahan serangga di jalan Soekarno Hatta Palembang.

\section{Kesimpulan}

Berdasarkan jumlah spesies dari masing-masing lokasi/stasiun survei menunjukan bahwa di ST1 (Rawa alami) ditemukan 77 spesies dengan kelimpahan 1002 individu $/ \mathrm{m}^{2}$, ST2 (Rawa yang telah ditimbun) ditemukan 53 serangga dengan kelimpahan 786 individu/m2, ST3 (Rawa yang telah dijadikan pemukiman) ditemukan 50 spesies dengan kelimpahan 498 individu/m2, dan ST4 (Rawa yang telah dijadikan perukoan) ditemukan 57 spesies dengan kelimpahan 723 individu $/ \mathrm{m}^{2}$. Hasil penelitian menunjukan bahwa pada ST1 (rawa alami) ditemukan spesies serangga terbanyak dibandingkan stasiun lainnya.

Keanekaragaman dan kelimpahan serangga di rawa alami lebih tinggi dibandingkan dengan zona rawa yang lain, hal ini akibat konversi/pembukaan lahan rawa yang secara ekologis berpengaruh terhadap struktur, komposisi dan fungsi dari rawa jalan Soekarno Hatta Palembang. Tutupan vegetasi semakin berkurang, fauna kehilangan habitat, kematian flora dan fauna, terjadi perubahan cuaca, dan mata air. Lebih jauh kerusakan rawa akan mengakibatkan kerusakan biotik dan abiotik yang sangat mempengaruhi fungsi kawasan serta kehidupan serangga. Hasil penelitian ini menunjukan bahwa konversi lahan rawa menyebabkan terjadinya dominasi spesies serangga tertentu serta penurunan keanekaragaman dan kelimpahan serangga di jalan Soekarno Hatta Palembang.

\section{Ucapan Terima Kasih}

Terima kasih kami ucapkan kepada semua pihak yang telah membantu baik moril maupun materil sehingga tulisan ini bisa kami selesaikan

\section{Daftar Pustaka}

Badan Perencanaan Pembangunan Nasional (1993). Keanekaragaman Hayati di Indonesia. http://www.bappenas.go.id/.

Borror, D.J., Triplehorn, C.A. \& Jhonson, N. F. (1992). Terjemahan Pengenalan Pelajaran Serangga. Yogyakarta: Gadjah Mada University Press.

Brotowidjoyo, Mukayat (1994). Zoologi Dasar. Erlangga: Jakarta

Departemen Kesehatan RI. (2002). Cara Pengendalian Kecoa. http://www.depkes.go.id/.

Febriana, Endang (2008). Kinerja Pengendalian Pemanfaatan Lahan Rawa di Kota Palembang. Skripsi. Semarang: Fakultas Teknik Universitas Diponegoro.

Hadi, M. (2009). Biologi Insekta. Yogyakarta: Graha Ilmu.

Junita, Vera (2014). Keanekaragaman dan Kelimpahan Serangga Ordo Diptera di DAS Musi Wilayah Kecamatan Gandus dan Sumbangannya pada Pembelajaran Biologi di SMA. Skripsi. Palembang: FKIP Universitas Sriwijaya

Khan, et al. (2007). Survey of predatory Coccinellids (Coleoptera: Coccinellidae) in the Chitral District. Pakistan. Journal of Insect Science, 7:7. DOI: 10.1673/031.007.0701

Lan, SU, H. Jun-hao, WO. Ming \& WU. Hong (2012). Insect diversity in wetland vegetation succession: A review. Chinese Journal of Ecology,31(6):1577-1584. http://www.cje.net.cn/EN/abstract/abstract6081.s html\#. 
Mathias, Erya Daniel (2015). Makalah Entomologi (Ordo Mantodea).

http://dokumen.tips/documents/makalahentomologi-ordo-mantodea-new.html.

Michael P. (1995). Metode Ekologi untuk Penyelidikan Lapangan dan Laboratorium. Dialihbahasakan oleh: Yanti R. Koester. UI Press. Jakarta.

Moch. Nazir (2003). Metode Penelitian. Salemba Empat: Jakarta.

Nursito, Cesa Dwi (2015). Hidrologi dan Lingkungan Studi Kasus Rawa di Kota Palembang Sumatera Selatan. Skripsi. Banjarmasin: FKIP Universitas Lambung Mangkurat.

Odum, EP. (1983). Dasar-dasar Ekologi. Terjemahan Samingan, et al. Yogyakarta: Universitas Gadjah Mada Press.

Pracaya, Ir. (2009). Hama dan Penyakit Tanaman. Jakarta: Penebar Swadaya.

Purba, Ika Rosenta (2002). Pengaruh Kegiatan Pertanian dan Pemukiman Terhadap Kualitas Air dan Keanekaragaman Makrozoobenthos (Studi Kasus Kecamatan Purba Kabupaten Simalungun). Skripsi. Medan: Universitas Sumatera Utara.

Putri, I.A.S.L.P \& Allo, M.K. (2007). Degradasi Keanekaragaman Hayati Taman Nasional Rawa Aopa Watumohai. Jurnal Penelitian Hutan dan Air Tawar, IV (2): 169-194. DOI: 10.20886/jphka.2009.6.2.169-194.

Rasdi Z M, Fauziah I, Ismail R, Hafezan M S, Fairuz K, Hazmi A. D. \& Che Salmah M.R. (2012). Diversity of Aquatic Insects in Keniam River, National Park, Pahang, Malaysia. Asian Journal of Agriculture and Rural Development, 2 (3): 312-328. DOI: 10.22004/ag.econ.197977

Shofix, Azmi (2012). Analisis Formulasi Kebijakan Publik (Studi pada Proses Perumusan Rancangan Peraturan Daerah Kota Palembang Tentang Pembinaan, Pengendalian dan Pemanfaatan Rawa). Skripsi. Indralaya: FISIP Universitas Sriwijaya.

Subagya, et al. (2006). Karakteristik dan Pengelolaan Lahan Rawa. Bogor: Balai Besar Penelitian dan Pengembangan Sumberdaya Lahan Pertanian.
Syahrawati, My \& Hamid, Hasmiandi (2010). Diversitas Coccinellidae Predator pada Pertanaman Sayuran di Kota Padang. repository.unand.ac.id/6412/1/artkl_mysyahra wati.pdf.

Taib, Minarti (2013). Ekologi Semut Api (Solenopsis invicta).http://download.portalgaruda.org/articl e.php?article $=137507 \& \mathrm{val}=3591$.

Teristiandi, Novin (2018). Freshwater Molluscs as Bioindicator of $\mathrm{Fe}$ and $\mathrm{Mn}$ Contamination in Lematang River, South Sumatera, Indonesia. E3S Web of Conferences 68. Doi: $10.1051 / \mathrm{e} 3$ sconf/2018680101

Tim Pendidikan Lingkungan Hidup (2007). Mengenal Undur-undur. Malang: Divisi Penerbitan dan Dokumentasi PPLH Seloliman Malang Science Research Institution 